\title{
Antioxidant Potential of Polyphenols: In Need for Critical Assessment of In Vitro Results
}

\section{Maleš $\check{Z}^{1 *}$ and Bojić $\mathbf{M}^{2}$}

${ }^{1}$ University of Zagreb, Department of Pharmaceutical Botany, Faculty of Pharmacy and Biochemistry, Croatia

${ }^{2}$ Department of Medicinal Chemistry, University of Zagreb, A. Kovačića 1, Croatia

"Corresponding author: Željan Maleš, Full Professor, Head of the Department of Pharmaceutical Botany, Faculty of Pharmacy and Biochemistry, University of Zagreb, Schrottova 39, HR-10000 Zagreb, Croatia, Tel: 3851 4683-051; E-mail: zmales@pharma.hr

Received date: March 31, 2016; Accepted date: April 04, 2016; Published date: April 08, 2016

Copyright: (C) 2016 Maleš Ž, et al. This is an open-access article distributed under the terms of the Creative Commons Attribution License, which permits unrestricted use, distribution, and reproduction in any medium, provided the original author and source are credited.

\section{Editorial}

Antioxidants have become OTC (Over the Counter) prophylactic dietary supplements hit of the $21^{\text {st }}$ century. Polyphenols, including flavonoids and phenolic acids, are widely distributed antioxidants and are present in medicinal drugs, fruits and vegetables (food) e.g. propolis, wine, chocolate... [1]. Individuals tend to reach for polyphenols as a source of longevity which can be related to their ability to reduce oxidative stress. Oxidative stress has been postulated as a cause of many diseases e.g. rheumatoid arthritis, diabetes, skin diseases, cataract, Alzheimer and Parkinson disease... Question that we often face is how effective commercially available product as antioxidants is. Predominantly this answer is gained through in vitro testing that includes spectrophotometry and chromatography.

Spectrophotometry methods of choice determine quantity of polyphenols or their antioxidant potential. The Folin-Ciocalteu method is used for quantification of total polyphenols and is based on the reduction of $\mathrm{MoO}^{4+}$ to $\mathrm{MoO}^{3+}$ that can be monitored at $765 \mathrm{~nm}$ as change in color from yellow to blue. Polyphenols in propolis, wine, herbal drugs and foods have been determined by this method [2]. Total content of flavonoids can be determined by Christ-Müller's method after acid hydrolysis as liberated aglycones in a complex with $\mathrm{Al}^{3+}$ in a methanol-ethyl acetate-acetic acid medium at $425 \mathrm{~nm}$. This method is effective in determining of content of flavonoids in medicinal plants, e.g. Rhamnus and Frangula species [3]. Total phenolic acids can be determined by measuring the absorbance of a complex formed between phenolic acids and sodium molybdate / nitrite at $505 \mathrm{~nm}$. This is official method for determination of rosmarinic acid in Melissae folium, and has been successfully employed in determination of phenolic acids in Ilex leaves [4]. Total polyphenols, non-tannin polyphenols and tannins can simultaneously be determined by a spectrophotometric method using phosphorous-tungsten acid and hide powder e.g. Teucrium sp. [5].

Potential of polyphenols as antioxidants can be assessed using free stable colored radicals like 2,2-diphenyl-1-picrylhydrazyl (DPPH) and 2,2'-azino-bis(3-ethylbenzothiazoline-6-sulphonic acid) (ABTS). While DPPH comes in radical form, ABTS has to be activated with potassium persulphate. In ABTS test radical reduction is accompanied by change from blue-green and DPPH from violet to yellow. Loss of color is monitored at $730 \mathrm{~nm}$ and $518 \mathrm{~nm}$, respectively. These methods have quite often been used for antioxidant potential assessment of foods and medicinal plants [2,6,7]. These are just some of the most used spectrophotometric methods, although list of methods for determination of polyphenols and their activity is rather extensive.
Results of spectrophotometric tests for determination of total polyphenols are usually expressed as equivalents of one phenolic acid or flavonoid e.g. gallic acid or quercetine. Expressing results of antioxidant is less uniform. It goes from expressing just percentage of discoloration compared to control, $\mathrm{IC}_{50}$ to more complex kinetic models. Although percentage of discoloration is easy to express it is highly dependent on experimental conditions and results of one research cannot be easily extrapolated and compared. Ascorbic acid and tocoferol are often used as controls and results should be expressed as equivalents of either of these vitamins or another polyphenol. While this will be satisfactory for most heterogeneous samples, problems emerge with similar samples with high antioxidant potential, e.g. propolis where expressing kinetic parameters was of use [8].

Most widely known and used antioxidants rich in polyphenols are propolis and wine. Beneficial effect of wine is well known under a catchphrase French paradox, while propolis has been in use mostly because of it antimicrobial potential. Both propolis and wine are complex mixture from which polyphenols can easily be separated and analyzed by liquid chromatography. As flavonoids and phenolic acids are UV active reverse phase High Performance Liquid Chromatography with Diode Array Detector (HPLC-DAD), as well as High Performance Thin Layer Chromatography (HPTLC) with densitometry are methods of choice. HPLC and HPTLC have been used in separation, determination and quantification of polyphenols in wine, propolis and medicinal plants [1,9]. As assessors of scientific manuscripts most common mistake we observe is tendency to determine and quantify individual polyphenols by chromatography and, at the end, come to a conclusion about total polyphenols as a sum of individual compounds. HPLC and HPTLC will not give an answer about total polyphenols content, spectrophotometric methods should be used for determination of total content.

Polyphenols have potential for many beneficial effects on human health. It has been shown that propolis consumption decreases malonaldehyde production (degradation product of peroxidation of polyunsaturated fatty acids) by $23.2 \%$ and increases superoxide dismutase activity (antioxidant enzyme) by $20.9 \%$. This observation was sex dependent [10]. In vitro tests of platelet aggregation showed that flavonoids reduce platelet aggregation in concentrations that can be achieved in vivo. Moreover, flavonoids can interfere with diagnosis of von Willebrand factor related blood clothing disorders [11].

Many of pharmacological actions of polyphenols can be related to their antioxidant activity; same was has also been observed in platelet function tests. However, it should be noted that doses used and concentrations achieved in blood, as flavonoids can also have proaggregatory effect depending of concentration [11]. Thus the same 
Citation: Maleš Ž, Bojic M (2016) Antioxidant Potential of Polyphenols: In Need for Critical Assessment of In Vitro Results. J Pharmacogn Nat

Page 2 of 2

as for vitamins, exposure to polyphenols should not go above the recommended daily values. It should also be noted that data from in vitro studies cannot easily be extrapolated to in vivo observations, as in vitro data tends to overestimate the pharmacological effect.

\section{References:}

1. Medić-Šarić M, Rastija V, Bojić M, Maleš Ž (2009) From functional food to medicinal product: systematic approach in analysis of polyphenolics from propolis and wine. Nutr J 22: 8:33.

2. Vinković-Vrček I, Bojić M, Žuntar I, Mendaš G, Medić-Šarić M (2012) Phenol content, antioxidant activity and metal composition of Croatian wines deriving from organically and conventionally grown grapes. Food Chem 124: 354-361.

3. Maleš Ž, Kremer D, Gašpar Randić Z, Randić M, Hazler Pilepić K, Bojić M (2010) Quantitative Analysis of Glucofrangulins and Phenolic Compounds in Croatian Rhamnus and Frangula Species. Acta Biol Crac Ser Bot 52: 108-113.

4. Bojić M, Simon Haas V, Šarić D, Maleš Ž (2013) Determination of Flavonoids, Phenolic Acids, and Xanthines in Mate Tea (Ilex paraguariensis St.-Hil.). J Anal Methods Chem 2013: 658596.
5. Maleš Ž, Hazler Pilepić K, Bojić M, Tatalović Z (2015) Determination of the content of total polyphenols, non-tannin polyphenols and tannins in five species of the genus Teucrium L. Period Biol 117: 453-455.

6. Brantner AH, Pfeifhofer HW, Ercegovac O, Maleš Ž, Plazibat M (2005) Essential oil composition and antioxidant activity of Thymus bracteosus Vis. ex Benth. Flavour Fragr J 20: 596-600.

7. Plazonić A, Mornar A, Maleš Ž, Kujundžić N (2013) Phenolic Content and Antioxidant Activities of Burr Parsley (Caucalis platycarpos L.). Molecules 18: 8666-8681.

8. Jasprica I, Bojić M, Mornar A, Bešić E, Bućan K, Medić-Šarić M (2007) Evaluation of antioxidative activity of Croatian propolis samples using $\mathrm{DPPH}^{*}$ and $\mathrm{ABTS}^{*}+$ stable free radical assays. Molecules 12: 1006-1021.

9. Maleš Ž, Medić-Šarić M (2001) Optimization of TLC analysis of flavonoids and phenolic acids of Helleborus atrorubens Waldst. et Kit. J Pharm Biomed Anal 24: 353-359.

10. Jasprica I, Mornar A, Debeljak Ž, Smolčić-Bubalo A, Medić-Šarić M, et al (2007) In vivo study of propolis supplementation effects on antioxidative status and red blood cells. J Ethnopharmacol 110: 548-554.

11. Bojić M, Debeljak Ž, Medić-Šarić M, Tomičić M (2012) Interference of selected flavonoid aglycons in platelet aggregation assays. Clin Chem Lab Med 250: 1403-1408. 